\title{
敬迎波萰科祭院代表團和各人民民主國家 的科四家訪問我國
}

社論

在今年偉大的五一節前後, 中國科學工作者 熱烈地、兄弟般地接待了来我國訫問的以没閨科 學院副院長士木工程學缘維日比茨基院士第首的 波麗科學院代表團，逭個代表團的棦員有著名的 數學家庫拉托夫斯基院士和力學家諾瓦茨基通訊 院士、歴史學家羅津斯基敉授; 我們也同樈接待 了匈牙利科學院副院長利格奇・萊奧士院士以及 其他人民民主國家的科學家們。中國科學工作者 襄心地歡迎他們，並且篇我國科學工作者與各人 民民主國家科學工作者之間的友誼的日益垡固與 诲展而感到興窟。

解放以來短短的幾年襄，我們和各人民民主 國家已經在员誠友好、互相琗助的基礎上建立了 緊密的科學與技術合作的關係: 我國同波蘭、捷 克斯洛伐兑、德意志民主共和國、匈牙利、程馬

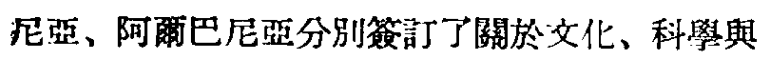
技術的合作協定，同時我門也和朝鮮导主主義背 和國、蒙古分別签訂了經濟及一文化合作協定。每 一年都有很多人民民主國傢的優秀科學家来我國 竍閣; 每一年我們也派出很多科學家到各個人民 民主國家去培問和參加一些重要的科學會議。我 國和各人民民主國家每年都相互遗派留學生。我 㥃的科學機㴖和备人民民主國家科學機構經常相

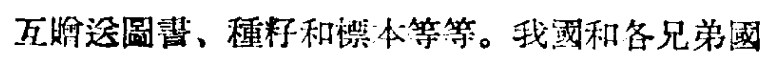
家科學交流的規模正诖逐年搌大。

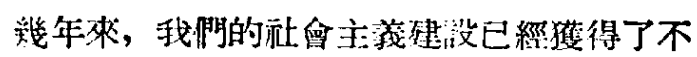

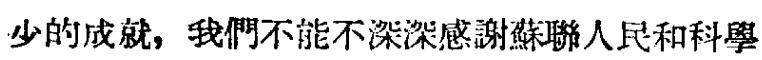
家給予我們的员誠佂私的援助，同時，我們也不 能不深潹感謝各人民民主國管的人民和科學家所 粭予我門的同樣氮誠無私的挼助。去年第了我們

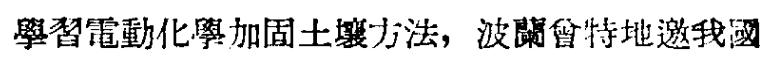

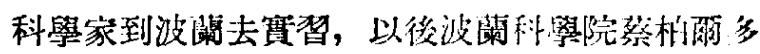
維契院士又親自到我國來聲助我門。由於使用了

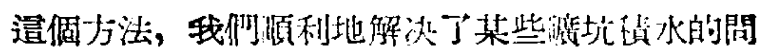

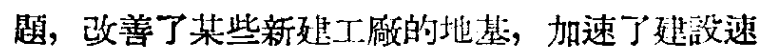

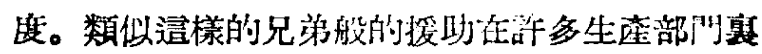
都可以看到。現在各人民民主國家還派有許多尃 家在我國到助我們進行社會主義建設，給我國大 量的技術資料，堼助我們培䔄技術幹部。

毛主席在第一国全國人民代表大會開幕訶中

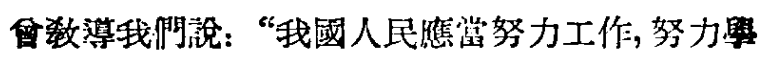
習蘇聯和各兄弟國家的先進經驗，老老實蒉，勤

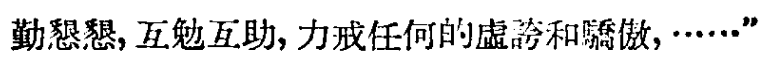
毛主磨的話我們是應該宋牛記住的。人荫知䢔, 很多人民主主國家的柆會主義建設都走在我們的 前面。它們有着比較好的工業岱濋, 世有着光榮 的科學傅統。第人類永邀流憶着的偉大的科學家

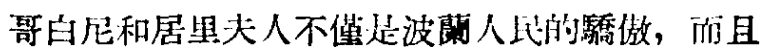

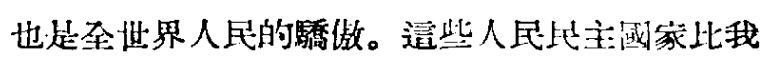

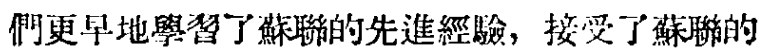
各方面的援助, 更早地在馬克思列密主義思想指 導下改造了自己的科學。他們正䍐我們學替的榜 樣。

中國科學工作者願新盡力第加强我國和各人 民民主國傢之間的科學合作與交流而努力，我們 要虚心向各兄弟國家䁷柏，我們也將向兄弟國家 提传我們的一切對他們有用的科學知識。中國科 學工作者深深相信，中國和各人民民主划傢利䑁

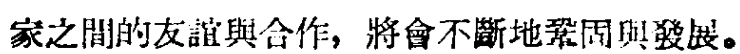

